\section{Cents and Sociability}

\section{Household Income and Social Capital in Rural Tanzania}

Deepa Narayan

Lant Pritchett
Matching a measure of social capital with data on

household income in certain rural villages in Tanzania shows that "social capital" is indeed both capital fin that it raises incomes) and social (in that household incomes depend on viltage, not just household, social capital).

The World Bank

Social Development and

Development Research Group

Poverty and Human Resources

July 1997 


\section{Summary findings}

Narayan and Pritchett construct a measure of "social capital" in rural Tanzania, using data from the Tanzania Social Capital and Poverty Survey (SCPS), a large-scale survey that asked individuals about the extent and characteristics of their associational activity and their trust in various institutions and individuals.

They match this measure of social capital with data on household income in the same villages (both from the SCPS and from an earlier household survey, the Human Resources Development Survey). In doing so, they show that "social capital" is indeed both capital (in that it raises incomes) and social (in that household incomes depend on village, not just household, social capital).
The magnitude of social capital's effect on incomes is impressive: a one standard deviation increase in village social capital increases a household proxy for income by at least 20 to 30 percent.

This is as great an impact as an equivalent increase in nonfarming assets, or a tripling of the level of education.

Data from the two surveys make it possible to identify some of the proximate channels through which social capital affects incomes: better publicly provided services, more community activity, greater use of modern agricultural inputs, and greater use of credit in agriculture.

This paper - a joint product of Social Development, and Poverty and Human Resources, Development Research Groupis part of a larger effort in the Bank to understand the social determinants of sustainable development. Copies of the paper are available free from the World Bank, $1818 \mathrm{H}$ Street NW, Washington, DC 20433. Please contact Sheila Fallon, room N8-030, telephone 202-473-8009, fax 202-522-1153, Internet address sfallon@worldbank.org. July 1997. (41 pages)

The Policy Research Working Paper Series disseminates the findings of work in progress to encourage the exchange of ideas about development issues. An objective of the series is to get the findings out quickly, even if the presentations are less than fully polished. The papers carry the names of the authors and should be cited accordingly. The findings, interpretations, and conclusions expressed in this paper are entirely those of the authors. They do not necessarily represent the view of the World Bank, its Executive Directors, or the countries they represent. 


\title{
Cents and Sociability: \\ Household Income and Social Capital in Rural Tanzania
}

\author{
Deepa Narayan \\ Lant Pritchett
}





\section{Cents and Sociability: \\ Household Income and Social Capital in Rural Tanzania ${ }^{1}$}

Beyond apparently now old fashioned "physical" capital, human capital, natural capital, institutional capital and social capital all clamor for attention. With capitalism all the rage, perhaps the proliferating rechristenings as "capital" of otherwise perfectly serviceable concepts is understandable. But fashion aside, the popularity of "capital"isms is due in part to the robust usefulness of the underlying metaphor: stuff that augments incomes but is not totally consumed in use. The attraction of investigating the incomes of households by examining their ownership of the various "capitals" is obvious. However, while obvious, an exclusive focus on households is seriously incomplete. Factors both at the national level of policies and institutions (Olson, 1996) and at the community level affect the fortunes of households and are potentially as important as the household's own capitals.

In this paper we show that associational relationships and social norms of villages in rural Tanzania are both capital and social. After outlining the various concepts of social capital in the introduction we tell how (and why) we created data on social capital using a large

1 The Social Capital and Poverty Survey was conducted as part of a Participatory Poverty Assessment led by Deepa Narayan as a joint activity of the government of Tanzania, the University of Dar Es Salaam, and the World Bank, funded by the British Overseas Development Agency. The Human Resource Development Survey data used in this paper come from a nationally representative survey of 5,000 households in Tanzania which was a joint effort undertaken by the Department of Economics of the University of Dar es Salaam, the Government of Tanzania, and the World Bank, and was funded by the World Bank, the government of Japan, and the British Overseas Development Agency. We would like to thank Jonathan Isham, and Sushenjit Bandopadhyay for collaboration in the early stages of the research, Christiaan Grootaert, Dean Joliffe, Michael Kremer, Peter Lanjouw, and Jonathan Morduch for useful comments, and Deon Filmer for help and insights on the econometrics. 
scale household survey in rural Tanzania designed to query households about their social connections and attitudes. Second, using this and data on incomes we show that a village's social capital has an effect on incomes of the households in that village, an effect that is empirically large, definitely social, and plausibly causal. Finally, we use the two data sets to examine a number of proximate channels through which social capital appears to operate.

\section{Introduction}

Social capital, while not all things to all people, is many things to many people. A dramatic restriction of what one might mean must precede any attempt to estimate either "social capital" or its impact. What do we mean (and what do we not mean) by social capital and why do we think it might affect incomes?

By "social capital" we mean the quantity and quality of associational life and the related social norms. The basic survey instrument, the Social Capital and Poverty Survey (SCPS), asked individuals a variety of questions about three dimensions of social capital. First, individuals were queried about their membership in various voluntary associations or groups to investigate the raw magnitude. For each group in which an individual reported membership, questions were asked about that group's characteristics in several dimensions relevant to that group's contribution to social capital. For instance, if the group's membership is "inclusive" we assumed any given individual's membership in that group contributed more to social capital than membership in a group in which membership is "exclusive" to a particular clan or ethnic group. With this data on the frequency of membership and the characteristics of groups we created an index of the village associational life, which we argue is a proxy for social capital. 
In addition to the information on associational life we sought to explore the existence and role of social and civic norms and individual's attitudes towards others, focusing in particular on the degree of trust individuals felt towards social groups, such as family, village or tribe, and towards government authorities, at the local, district, and national level.

While social capital thus defined as the quantity and quality of local associational life is clearly social, is it "capital"? Does it fit the "capital" metaphor of something accumulated which contributes to higher income (or, more broadly, better outcomes). Five mechanisms have been proposed for how local social capital affects outcomes. From an economist's viewpoint, all of these share the characteristic that pure non-cooperative action would lead to inferior outcomes and hence that greater social capital potentially leads to better outcomes by facilitating greater cooperation.

First, Putnam's (1993) fascinating analysis of the variations in public sector efficacy of the newly created regional governments in Italy suggests that regions of Italy in which people had greater degrees of horizontal connections had more efficacious governments. He documents a close connection between the numbers of voluntary associations and the efficacy of the regional government. Putnam finds that the more likely a region's citizens are to join football clubs and choral societies the faster the regional government is in reimbursing health care claims. One way of understanding this result is that monitoring the performance of the government is facilitated by greater social capital, either directly, because the government agents themselves are more embedded in the social network or perhaps indirectly because the monitoring of the public provision of services is a public good (and this is true even if the 
publicly provided service is itself a private good as long as quality cannot be individually differentiated $)^{2}$.

Second, independent of the efficacy of governmental activity the role of group or community cooperative action in solving problems with a local "common property" elements is potentially important. Ostrom's (1990) work suggests that the ability of local groups to cooperate plays a large role in avoiding the negative consequences of the excessive exploitation or under maintenance of assets that would result from purely individualistic behavior under open access. She points out that the infamous "tragedy of the commons" based on purely individualistic behavior is only one possible outcome and that cooperative action can be a stable outcome. Ajuha (1996) shows that in Cote d'Ivoire the degree of land degradation is worse in more ethnically heterogenous villages, suggesting difference in the effectiveness of community controls and cooperation depends on social factors. Wade (1988) documents wide differences in the extent of cooperation within villages in Southern India, which he attributes to a significant degree to differences in the benefits from cooperation due to differences in the physical characteristics of the irrigation network serving the villages. Social capital may facilitate greater cooperation in the provision of services which benefit all members of the community.

2 Alesina, Baqir, and Easterly (1997) show that greater ethnic fragmentation in US cities leads to lower spending on productive public goods (e.g. education, roads, sewers) and is negatively related to the share of local spending on welfare. While not able to measure efficacy directly, the results also suggest higher public employment with greater fragmentation, possibly the results of higher patronage. 
Third, diffusion of innovations might be facilitated by greater linkages among individuals. In his review of empirical work on the diffusion of innovations Rogers (1983) reports studies which suggest that "social participation," "interconnectedness with the social system," "exposure to interpersonal communication channels" and "belonging to highly interconnected systems" are each positively associated with the early adoption of innovations. Recent research on the adoption of Green Revolution innovations suggest that village level spillovers played a role in individuals' adoption decisions, but do not examine the role that social capital may have played in mediating the village level effects (Besley and Case 1994, Foster and Rosenzweig 1995).

Fourth, greater associational activity may lead to less imperfect information and hence lower transactions costs and a greater range of market transactions in outputs, credit, land and labor leading to higher incomes. Social links among parties to economic transactions may increase their ability to participate in economic transactions which involve some uncertainty about compliance, like credit. There are two possible mechanisms at work. Social capital could lead to a better flow of information between creditors and borrowers and hence less adverse selection and moral hazard in the market for credit. Social capital also potentially expands the range of enforcement mechanisms for default on obligations in environments in which recourse to the legal system is costly or impossible.

Fifth, greater sharing of household risk and informal insurance may allow households to pursue higher return but more risky activities and production techniques. If this is so then a social safety net that mitigated the consequences of adverse outcomes would lead farmers to 
undertake higher return but also higher risk activities (Morduch, 1995). Increased social capital could lead to greater risk sharing among villagers and act as an informal safety net.

What do we not mean by social capital? There are many other equally plausible and perhaps empirically important definitions of "social capital" which we do not explore. In order to distinguish our work from the previous literature it helps to begin with a more general definition. In the abstract a "society" can be thought of as a series of nodes (e.g. individuals, households) and a set of connections between those nodes. The connections between the nodes can be any kind of relationship whether social relationship (e.g. familial, ethnic), shared beliefs (e.g. religious), group identification (e.g. national, local) or a voluntary association, whether economic (e.g. employee, creditor) or non-economic (e.g. social club). Different notions of social capital can be distinguished by two features. First, whether the focus is on the nodes themselves, and hence on individual's social ties, or on the connections between the nodes, the intrinsically social. The second distinguishing feature of the existing empirical studies on social capital is the specification of what "connections" between individuals are counted and how much weight each different type of link should receive.

While we examine the social by examining the effect of the density of associational life on village outcomes, there is a considerable body of work on "social capital" that examines individual's ownership of social capital by examining the worth of each individual's social connection to other nodes. The emphasis is on the effects on the individual of having social links to valuable nodes, like having a rich uncle, or growing up in a good neighborhood (Case and Katz, 1991), or being a member of a successful ethnic group (Borjas, 1994). 
We examine the links between individuals created by memberships in voluntary associations and social norms, which potentially excludes other dimensions of social capital. First, we do not examine the impact of any sense of affiliation with a nation or nation-state or any measure of distributional or ethnic conflict within the polity ${ }^{3}$. Second, we do not examine as "capital" the institutional "capacity" either of specific government or non-government organizations nor in the broad sense of society possessing a well known and legally sanctioned set of "rules of the game." Third, we do not analyze any "cultural" values or attitudes, such as degrees of compassion, altruism, respect, tolerance ${ }^{4}$. Fourth we do not examine the issues explored recently by Knack and Keefer (1996) on the relationship between trust, norms of civic cooperation, associational activity and aggregate economic growth and investment rates.

\section{Data on Social Capital?}

We cannot examine the effects of what we mean by social capital, only what we measure. The sections below describe the survey and the procedure we used to construct our measure of social capital. The Social Capital and Poverty Survey (SCPS) was carried out in rural Tanzania in April and May of 1995 as part of a larger participatory poverty assessment exercise (Narayan, 1997). While the households were chosen randomly within clusters, the

3 Easterly and Levine (1996) have shown that a measure of "ethnic heterogeneity" is empirically associated with the adoption of bad economic policies, which they attribute to the importance of distributional conflict among groups.

4 Explaining economic performance by such "cultural" characteristics such as the "Protestant work ethnic" or "Confucianism" has a history which is long and checkered, as it easily veers to self-congratulation or condescension. Recent entries include Harrison (1992) on culture and Fukuyama's examination of trust (1995). 
sampling clusters themselves, which correspond roughly to villages in rural areas, were the same as those randomly selected for use in the 1993 Human Resource Development Survey (HRDS), hence the SCPS and HRDS data can be matched village by villages. The total usable SCPS sample is 1376 households located in 87 clusters $^{6}$.

Social capital module of SCPS. The survey's social capital component queried a household respondent about three dimensions of social capital: first, their membership in groups, second, the characteristics of those groups in which the households were members, third, the individuals values and attitudes, particularly their definition, and expressed level, of trust in various groups, and their perception of social cohesion. In this work we describe the groups only briefly, with a fuller description of the groups, their activities, and the results of qualitative information from interviews and participatory data collection methods in a companion paper (Narayan, 1997).

The first set of questions was simply the number of groups in which an individual was a member. The average number of groups per person was 1.5 and table 1 lists the most prevalent groups, individuals' responses as to their "most important" group and the groups they would join if they could join only one group. Most groups are Christian churches, Mosques, the village burial society, women's groups, and the political party. The more purely economic

s Also, rather than carry out new randomization, the households in the sample were the same as those sampled in the 1994/95 Agricultural Survey, with the addition of up to five nonagricultural households randomly selected within the cluster.

6 The survey was implemented in two parts, a social capital module and a household module devoted primarily to measuring household expenditures, but unfortunately the second part was only administered in every other cluster so only 53 clusters have SCPS expenditure data. 
associations (cooperatives, rotating credit groups) are much less important. In the construction of our measure of social capital we deliberately do not differentiate by type of group, as the main purpose is to examine whether groups with nor-economic functions have village level spillover effects on economic outcomes?

Table 1: Groups in rural Tanzania, by membership and characteristics

\begin{tabular}{|l|l|l|l|l|}
\hline & $\begin{array}{l}\text { Group as a } \\
\text { percent of } \\
\text { all } \\
\text { membership }\end{array}$ & $\begin{array}{l}\text { Number of } \\
\text { households } \\
\text { with } \\
\text { members }\end{array}$ & $\begin{array}{l}\text { "Most important } \\
\text { group in your } \\
\text { life at present?" }\end{array}$ & $\begin{array}{l}\text { "If you could join only } \\
\text { one group, which one } \\
\text { would it be?" }\end{array}$ \\
\hline Church & 21 & 230 & 29 & 24 \\
\hline $\begin{array}{l}\text { Political party } \\
\text { (CCM) }\end{array}$ & 17 & 195 & 10 & 3 \\
\hline Burial society & 15 & 167 & 19 & 14 \\
\hline Women's group & 9 & 104 & 5 & 8 \\
\hline Muslim group & 9 & 109 & 11 & 8 \\
\hline Farmer's group & 8 & 87 & 8 & 16 \\
\hline Other & 21 & 252 & - & - \\
\hline $\begin{array}{l}\text { Notes: In this table "Other" includes (with percent reporting): Youth group (7), Primary } \\
\text { society (4), Cooperative (2), Rotating Credit Societies (2), Dairy/cattle (1) and Other (5). }\end{array}$ \\
\hline
\end{tabular}

In addition to questions about membership a second set of questions were asked about the characteristics of the each group in which the individuals reported membership. These were grouped into five categories: 1) kin heterogeneity of membership, 2) income heterogeneity of membership, 3) group functioning, 4) group decision making, and 5)

7 Early results suggested that excluding economic groups altogether had very little influence on the findings, as would be expected given their small share. 
voluntary membership. The five questions in the three categories listed in detail in table 2 were those that proved useful in defining social capital for the empirical analysis below ${ }^{8}$.

Earlier work on this data set used principal components to create an index but this was . abandoned for three reasons. First, using a multiplicative rather than an additive index to combine membership and characteristics was appropriate. Second, the principal components methodology was not appropriate as the inter-correlations amongst these dimensions are not particularly high (the first principal component only "explained" 35 percent of the total variation). Third, the results on the first principal component alone were not robust when extended to other data and variables. 


\begin{tabular}{|c|c|c|c|}
\hline & Question & Responses & Freq. \\
\hline $\begin{array}{l}\text { Number of } \\
\text { groups }\end{array}$ & $\begin{array}{l}\text { How many [from a prompted } \\
\text { enumeration of groups in the } \\
\text { village] are you a member of? }\end{array}$ & $\begin{array}{l}0 \\
1 \\
2 \\
3 \text { or greater }\end{array}$ & $\begin{array}{l}32.3 \\
40.4 \\
17.4 \\
9.9\end{array}$ \\
\hline \multicolumn{4}{|c|}{ Answers to questions below recorded for up to three groups for each individual: } \\
\hline $\begin{array}{l}\text { Kin } \\
\text { Heterogeneity }\end{array}$ & $\begin{array}{l}\text { Who are [the group's] members? } \\
\text { Are they the same kin or the same } \\
\text { clan? }\end{array}$ & $\begin{array}{l}\text { 1-Close relatives } \\
\text { 2-Same clan } \\
\text { 3-Different tribes } \\
\text { 4-Anyone in the village }\end{array}$ & $\begin{array}{l}1.09 \\
2.95 \\
25.7 \\
70.2\end{array}$ \\
\hline \multirow[t]{2}{*}{$\begin{array}{l}\text { Income } \\
\text { Heterogeneity }\end{array}$} & $\begin{array}{l}\text { Are all members from the same } \\
\text { economic group, do they all make } \\
\text { a living in the same way? }\end{array}$ & $\begin{array}{l}\text { 1- All same livelihood } \\
\text { 2-Most are the same } \\
\text { 3-Mixed }\end{array}$ & $\begin{array}{l}5.7 \\
11.9 \\
82.3\end{array}$ \\
\hline & $\begin{array}{l}\text { Do the leaders or group officials } \\
\text { earn their living in the same way } \\
\text { as other members or in different } \\
\text { ways }\end{array}$ & $\begin{array}{l}\text { 1-Different livelihood } \\
\text { 2-Same livelihood }\end{array}$ & $\begin{array}{l}33.2 \\
66.7\end{array}$ \\
\hline \multirow[t]{2}{*}{$\begin{array}{l}\text { Group } \\
\text { functioning }\end{array}$} & $\begin{array}{l}\text { Overall, how would you rate the } \\
\text { group functioning? }\end{array}$ & $\begin{array}{l}\text { 1-Very poorly } \\
\text { 2-Poorly/weakly } \\
\text { 3-Average } \\
\text { 4-Good } \\
\text { 5-Excellent }\end{array}$ & $\begin{array}{l}2.1 \\
8.5 \\
23.7 \\
47.4 \\
18.3\end{array}$ \\
\hline & $\begin{array}{l}\text { If there is a fee, what happens if a } \\
\text { member does not pay the fee? }\end{array}$ & $\begin{array}{l}\text { 1-Asked to leave the group } \\
\text { 2-Delay in payment accepted } \\
\text { 3-Nothing happens }\end{array}$ & $\begin{array}{l}30.1 \\
17.4 \\
52.5\end{array}$ \\
\hline
\end{tabular}

To combine these questions into a single numerical index various strong (and arbitrary) assumptions were necessary about the weights and the aggregation. Since the variables are on different discrete scales, all the variables are first rescaled under the assumption that the observed indicator divided up evenly some underlying uniformly distributed continuous 
variable ranging from 0 to 100 into $\mathrm{N}$ categories 9 . Second, we assume that the contribution to social capital of being a member of each group was greater if the group was more heterogenous across kinship groups, more inclusive and horizontal, and better functioning. Hence the contribution of each group to social capital is an equally weighted sub-index of these three characteristics. The village level social capital index is the product of the average number of groups with the average characteristics of those groups. Since the absolute scale for this index is arbitrary we re-normalize the index to have mean zero and standard deviation one $e^{10}$.

Before examining the specific hypotheses about social capital, some information on the situation and activities of the people surveyed will set the context. Rural Tanzania is a clear case of arrested economic development. Tanzanians are very poor, the average per person consumption expenditures reported in the 1993/94 HRDS in nural areas is 50 cents a day ( $\$ 180$ per person per year) ${ }^{11}$. Most of the population is employed in traditional agriculture, with a substantial subsistence component as the imputed value of production for own consumption accounts for half of consumption expenditures. Nearly all agriculture is rain fed and uses

9 The numerical value to being the $\mathrm{k}^{\text {th }}$ of the $\mathrm{N}$, categories for the $\mathrm{l}^{\text {th }}$ indicator is: $V_{k, l}=\left(100 / N_{l}\right) * k-100 /\left(N_{l} * 2\right)$. As long as the value assigned to each category is the mean of the observations in that category this procedure will not induce inconsistency in the resulting estimates.

10 This is done using the mean and standard deviation for all 87 clusters. Therefore the samples used below may not have exactly mean zero/standard deviation one.

11 The World Development Report, 1995 reports Tanzania as tied with Mozambique for the lowest GNP per capita of $\$ 90$. 
almost no modern inputs (see table 8 below), is labor intensive depending primarily on household labor, and uses a few rudimentary tools with an almost complete lack of mechanization. The data from the HRDS confirm that the health and nutrition status of the population is very poor, with an infant mortality rate of 92 in $1991 / 92$ and 47 percent of children show signs of stunting. The government's past emphasis on primary schooling means that although many adults in rural households have primary schooling and the average years of schooling completed for adults is about 4.5, very few rural residents have secondary schooling.

\section{Social Capital and Incomes}

We show that associational life is in fact social capital first by showing it is capital and then by showing that this capital is social. After establishing a strong association between the social capital in a village and incomes of households in that village we use instrumental variables estimation to argue this association is due to higher social capital leading to higher incomes and not because higher incomes lead to greater associational life. We then show the impact of village social capital on household incomes is truly social, by showing that there is an independent effect at the village level.

Both the SCPS and HRDS collected data on the economic and demographic characteristics of households. Total consumption expenditures per person in the household were estimated, including imputations for own produced consumption and for consumer durables (e.g. housing). We use expenditures as a proxy for incomes (and use the terms interchangeably) for two reasons. First, when there is saving and dissaving (and especially with 
functioning capital markets) current expenditures are a better measure of permanent income than is current income. Second, extensive experience with household surveys has shown that it is tremendously difficult (if not impossible) to measure the incomes of the agrarian self-employed who constitute the bulk of our sample (Deaton, 1997).

In order to estimate the impact of social capital on incomes we first adopt a specification of the determinants of per person household expenditures that includes both individual (variables $\mathrm{Z}_{\mathrm{ij}}$ ) and village $\left(\mathrm{X}_{\mathrm{j}}\right)$ level variables ${ }^{12}$ :

$$
H_{i j}=\beta * \text { Social Capital } j+\alpha * Z_{i j}+\gamma * X_{j}+\epsilon_{i j}
$$

A number of household characteristics are included: the average years of schooling of male and female adults (over 20) in the household ${ }^{13}$, a dummy variable if the head of the household was "self-employed in agriculture," a dummy variable for female headed households and an index of non-land, non-agricultural, physical assets ${ }^{14}$.

12 This specification was previously developed and used in an examination of rural poverty in Tanzania (World Bank, 1995).

13 The average of both males and females adults is used for simplicity, although it is worth noting that when the genders are included separately the average education of adult females in the household had a much larger estimated impact on incomes than male schooling.

14 The index was created by assigning the following weights to ownership of the following assets if they are in working condition (in the SCPS); sewing machine, bicycle, car, motorcycle, van or truck, 16 , radio 8 , table 6 , clock, watch or bed 4 , chair 3 , lamps 2 . The HRDS has a less complete list of assets; bicycles 16 , radios or cameras 8 , watches 4 . Originally a weight of 400 was assigned to bicycle, car, motorcycle, van or truck, but the very few observations with ownership of those assets dominated the variation, so it was (regrettably and arbitrarily) reassigned a weight of 16 . 
There are two village level variables besides social capital. First, the median distance of dwellings in the cluster to a market for crops included as a proxy for the market integration of the village ${ }^{15}$. In addition, a set of dummy variables for six agro-climatic regions of Tanzania are also included to control partially for the economic and agro-climatic diversity of the country.

Is "social capital" capital? Column 1 of table 3 presents the results of OLS estimation of the partial correlation between a cluster's average household per person expenditures and social capital, controlling for this set of variables. The coefficient on the social capital index is empirically large and moderately statistically significant ( $p$-level .08). Households in villages with higher levels of social capital have significantly higher expenditures.

However, "social capital" or associational life may simply be a normal consumption good so that richer households consume more, that is, perhaps associational life is not "capital" but "consumption" consumed more by households with greater income or leisure ${ }^{16}$. If richer individuals live together then one would tend to find that richer villages are associated with higher village social capital. In the U.S., for example, the average income of neighborhoods would be associated with higher ownership of luxury cars, but this does not imply if poorer

is In the above mentioned World Bank study of rural poverty, distance to market was interacted with an index of road quality and produced a strong income effect. In our case we could not replicate the road quality index with our HRDS sample and so used the simpler, but less appealing, measure of distance alone.

${ }^{16}$ This argument is weakened by the fact that the social capital index is only partly a measure of associational activity, as it more reflects the nature of groups of which individuals are members which is at least plausibly less related to income that is the magnitude of activity. To use Putnam's illustration, it may well be that richer individuals bowl more but less clear why they should bowl more in groups when they do bowl (Putnam, 1995). 
neighborhoods had more Mercedes it would make them richer. We answer this objection about the direction of influence between social capital and income in three ways. In this section we use instrumental variables estimation while in the next section we show that it is the village's social capital that matters, not the individual's. The final section presents evidence on the different causal mechanisms by which social capital increases incomes. 


\begin{tabular}{|c|c|c|c|c|}
\hline \multicolumn{5}{|c|}{ Household Expenditures Per Person and Social Capital } \\
\hline Column: & 1 & 2 & 3 & 4 \\
\hline Source of Data: & \multicolumn{4}{|c|}{ Social Capital and Poverty Survey } \\
\hline Level of Data: & \multicolumn{2}{|c|}{ Cluster Averages } & \multicolumn{2}{|c|}{ Household } \\
\hline Estimation method ${ }^{1}$ : & OLS & IV (a) & $\mathrm{IV}^{3}(\mathrm{~A})$ & IV (B) \\
\hline Social Capital & $\begin{array}{l}.119 \\
1.80\end{array}$ & $\begin{array}{l}.496 \\
2.75\end{array}$ & $\begin{array}{r}.559 \\
5.37^{4}\end{array}$ & $\begin{array}{l}.345 \\
1.29\end{array}$ \\
\hline Household size & $\begin{array}{c}-.011 \\
.21\end{array}$ & $\begin{array}{l}-.033 \\
.424\end{array}$ & $\begin{array}{l}-.073 \\
8.66\end{array}$ & $\begin{array}{l}-.075 \\
6.21 \\
\end{array}$ \\
\hline Average adult schooling ${ }^{2}$ & $\begin{array}{l}-.030 \\
.789\end{array}$ & $\begin{array}{l}-.105 \\
1.66\end{array}$ & $\begin{array}{l}.0087 \\
.512\end{array}$ & $\begin{array}{l}.013 \\
.761\end{array}$ \\
\hline $\begin{array}{l}\text { Female head of household } \\
(1=\text { yes })\end{array}$ & $\begin{array}{l}-.439 \\
.714\end{array}$ & $\begin{array}{l}-.458 \\
.566\end{array}$ & $\begin{array}{l}-.090 \\
.810\end{array}$ & $\begin{array}{l}.070 \\
.676\end{array}$ \\
\hline Asset ownership (ln) ${ }^{2}$ & $\begin{array}{l}.102 \\
1.24\end{array}$ & $\begin{array}{l}-.038 \\
.297\end{array}$ & $\begin{array}{l}.176 \\
2.78\end{array}$ & $\begin{array}{l}.207 \\
3.58\end{array}$ \\
\hline $\begin{array}{l}\text { Self-employed in agriculture } \\
(1=\text { yes })\end{array}$ & $\begin{array}{l}-.99 \\
2.76\end{array}$ & $\begin{array}{r}-.975 \\
1.92\end{array}$ & $\begin{array}{l}-.207 \\
2.12\end{array}$ & $\begin{array}{l}-.203 \\
2.32\end{array}$ \\
\hline $\begin{array}{l}\text { Distance to nearest market } \\
\text { (cluster) }^{2}\end{array}$ & $\begin{array}{l}-.023 \\
1.57\end{array}$ & $\begin{array}{l}-.015 \\
.801\end{array}$ & $\begin{array}{l}.0062 \\
.286\end{array}$ & $\begin{array}{l}.0018 \\
.090\end{array}$ \\
\hline \multicolumn{5}{|l|}{ Agroclimatic zones 4} \\
\hline $\begin{array}{l}\text { Regression statistics } \\
\text { Number of Obs. } \\
\text { Adjusted R-Squared } \\
\text { First Stage Incremental R2 } \\
\text { Instrument test (p-level) }\end{array}$ & $\begin{array}{c}53 \\
.272 \\
- \\
--\end{array}$ & $\begin{array}{c}53 \\
- \\
.119 \\
.274\end{array}$ & $\begin{array}{c}846 \\
\cdots \\
.099 \\
.004\end{array}$ & $\begin{array}{c}846 \\
.072 \\
.345\end{array}$ \\
\hline \multicolumn{5}{|c|}{$\begin{array}{l}\text { Notes: 1) The t-statistics are Huber corrected standard errors that are heteroskedasticity consisten } \\
\text { and account for stratified random sampling. } \\
\text { 2) If observations for any of these variables for any households were missing, a value a missing } \\
\text { value dummy variable is set equal to one (not reported). } \\
\text { 3) The instrument sets are a: trust in strangers, tribesman, cell leader, village chairman } \\
\text { (government), district officials, central government while instrument set B excludes strangers. } \\
\text { 4) Included in the regressions but not reported are dummy variables for each of six agro-climatic } \\
\text { zones. }\end{array}$} \\
\hline
\end{tabular}

Instrumental variables estimation uses the correlation between social capital and another variable--the instrument--which is not determined by, and does not directly determine, income 
to estimate the impact of exogenous shifts in social capital on income. This eliminates the difficulty created by the potentially simultaneous determination of income and social capital. The drawback is that one must have valid instruments, and worse, the validity of an instrument depends entirely on theoretical arguments about the structure of the model since at least some set of the "just identifying" assumptions cannot be directly tested.

As mentioned above, questions were posed to households about individual's "trust" in various groups. We posit that certain of the these "trust" variables, particularly an individual's trust in strangers and trust in various government officials, are not affected directly by household income nor do they affect income directly, but that greater levels of trust do lead to higher village social capital ${ }^{17}$. Column 2 of table 3 shows the IV estimates of the social capital impact using cluster level data based on those assumptions. The estimated effect of social capital is substantially larger than the OLS estimates and is now strongly statistically significant. This supports a view that social capital is an exogenous determinant of income because if social capital were purely a consumption good and higher incomes led to greater social capital then the IV estimates of the effect of social capital should have been lower than the OLS estimates, instead of much higher. The higher estimate is consistent with a lack of joint determination of the two variables and a large degree of measurement error in our social capital variable since measurement error leads to bias towards zero ${ }^{18}$.

${ }^{17}$ A recent investigation using cross national data from the World Values Surveys does find a strong bivariate correlation between expressed degrees of trust and membership in associations (La Porta, Lopez-de-Silanes, Shleifer, and Vishny, 1997).

18 The fact that the IV estimates are higher may reflect measurement error in the village level social capital variable. Since we are using only between 15 to 20 households per cluster, the 
Columns 3 and 4 of table 3 show the same expenditure regressions at the household level. Using the household level data we get very similar results on social capital, a coefficient of .56 or .34 depending on the instrument set compared to .49 using the cluster level. Not surprisingly, the estimates on the control variables, such as education, are more reasonable using the household data.

The standard test for the exogeneity of the instrument set (which is essentially a test that trust does not itself cause higher incomes except through its effect on social capital) does not reject the instruments in the cluster data, but the test does reject the instrument set in the household data. The variable "trust in strangers" causes the instrument set rejection, which is puzzling as it is the most plausibly exogenous a priori as we thought trust in strangers would be the least likely to be affected by income or associational activity. Estimation using the household data without "trust in strangers" as an instrument provides a quantitatively similar (.34) but less precisely estimated (t-stat 1.27 ) coefficient on social capital and the exogeneity test is not rejected.

Is "social capital" social? The second question is whether participation in associational life raises incomes only of those who directly participate or whether social capital produces spillovers to other individuals. We can address this question in two compelling ways.

cluster level average social capital will contain a substantial component of measurement error in measuring the true cluster social capital. If this were a univariate regression, the ratio of the OLS to IV estimates is an estimate of the ratio of the true signal to the total variance. The estimates suggest the noise is very large. The correlation in repeated measurements is also a measure of the noise to signal ratio. While we do not have repeated measurements in the same villages for social capital, the correlation of the two village level estimates of expenditures per person is .45 , so if the magnitude of measurement error between the two variables is similar these are consistent. 
First, column 1 of table 4 shows the result of regressing household incomes on the social capital of the village (calculated net of each household's contribution to village social capital) and on the household's own social capital. All of the effect is due to the village level social capital and none is due to the household's own measured social capital. This finding is especially compelling because most of the variation in the social capital index is actually across households within the same village, which should make it easy to estimate the household effect precisely and difficult to estimate the village effect. 


\begin{tabular}{|c|c|c|c|c|}
\hline Column: & 1 & 2 & 3 & 4 \\
\hline Source of Data: & SCPS & \multicolumn{3}{|c|}{ Human Resource and Development Survey } \\
\hline Level of data: & Household & Cluster & \multicolumn{2}{|c|}{ Household } \\
\hline Type of estimation': & OLS & IV & $I V^{s}(a)$ & IV (B) \\
\hline Cluster Level Social Capital & $\begin{array}{l}.084 \\
1.10\end{array}$ & $\begin{array}{l}.208 \\
2.56\end{array}$ & $\begin{array}{l}.193 \\
2.31\end{array}$ & $\begin{array}{l}.227 \\
1.71\end{array}$ \\
\hline Household Level Social Capital ${ }^{3}$ & $\begin{array}{l}-.020 \\
.526\end{array}$ & & & \\
\hline Household size & $\begin{array}{l}-.077 \\
7.61\end{array}$ & $\begin{array}{l}.019 \\
1.04\end{array}$ & $\begin{array}{c}. .080 \\
10.5\end{array}$ & $\begin{array}{c}-.079 \\
10.3\end{array}$ \\
\hline Average adult schooling ${ }^{2}$ & $\begin{array}{l}.019 \\
1.43\end{array}$ & $\begin{array}{r}-.057 \\
1.42\end{array}$ & $\begin{array}{l}.021 \\
2.87\end{array}$ & $\begin{array}{l}.021 \\
2.79\end{array}$ \\
\hline Female head of household ( $1=$ yes) & $\begin{array}{l}-.041 \\
(.448)\end{array}$ & $\begin{array}{l}.345 \\
1.19\end{array}$ & $\begin{array}{r}-.009 \\
.150\end{array}$ & $\begin{array}{l}-.010 \\
.173\end{array}$ \\
\hline Asset ownership (ln) ${ }^{2}$ & $\begin{array}{l}.253 \\
4.40\end{array}$ & $\begin{array}{l}.245 \\
3.88\end{array}$ & $\begin{array}{l}.143 \\
5.26\end{array}$ & $\begin{array}{l}.143 \\
5.20\end{array}$ \\
\hline Self-employed in agriculture ( $1=$ yes) & $\begin{array}{c}-.193 \\
2.36\end{array}$ & $\begin{array}{r}-.325 \\
1.19\end{array}$ & $\begin{array}{c}-.068 \\
1.69\end{array}$ & $\begin{array}{c}-.069 \\
1.68\end{array}$ \\
\hline Distance to nearest market (clstr) $)^{2}$ & $\begin{array}{c}-.0036 \\
.243\end{array}$ & $\begin{array}{r}-.004 \\
1.05\end{array}$ & $\begin{array}{c}-.0087 \\
2.21\end{array}$ & $\begin{array}{c}-.0087 \\
2.21\end{array}$ \\
\hline \multicolumn{5}{|l|}{ Agroclimatic zone dummies ${ }^{4}$} \\
\hline $\begin{array}{l}\text { Regression statistics } \\
\text { Number of Observations } \\
\text { Adjusted R-Squared } \\
\text { First stage Incremental } R^{2} \\
\text { Instrument test ( } p \text {-level) }\end{array}$ & $\begin{array}{c}846 \\
.215 \\
- \\
-\end{array}$ & $\begin{array}{c}84 \\
- \\
.092 \\
.618\end{array}$ & $\begin{array}{c}1505 \\
- \\
.116 \\
.783\end{array}$ & $\begin{array}{c}1505 \\
- \\
.061 \\
.786\end{array}$ \\
\hline $\begin{array}{l}\text { Notes: 1) The t-statistics are based on } \\
\text { and account for stratified sampling. } \\
\text { 2) If any of these variables were missi } \\
\text { variable is set equal to one. } \\
\text { 3) Cluster level social capital index ex } \\
\text { 4) Included in the regressions but not } \\
\text { the three missing value dummy variabl } \\
\text { 5) The instrument sets are a: trust in } \\
\text { district officials, central government wl }\end{array}$ & $\begin{array}{l}\text { corrected sta } \\
\text { I a value was } \\
\text { household's } \\
\text { d are dummy } \\
\text { rs, tribesman } \\
\text { strument set I }\end{array}$ & $\begin{array}{l}\text { errors tha } \\
\text { ed for that } \\
\text { sponse. } \\
\text { les for eac } \\
\text { eader, vill } \\
\text { des strang }\end{array}$ & $\begin{array}{l}\text { cteroske } \\
\text { hold and } \\
x \text { agro-c } \\
\text { airman ( }\end{array}$ & $\begin{array}{l}\text { consistent } \\
\text { ng dummy } \\
\text { cones and } \\
\text { lent), }\end{array}$ \\
\hline
\end{tabular}


The second way we show that the social capital effect is a village, and not only a household, effect is to match the HRDS data on expenditure per household and other household and village characteristics with the SCPS data on social capital at the village level. The households surveyed to estimate expenditures are in the same villages but are not (except for possible coincidental repeats) the same households used to measure social capital. Column 2 of table 4 shows the results of regressing household incomes from the HRDS on social capital from the SCPS (and the other household and cluster variables calculated from the HRDS) using instrumental variables estimation. The estimated impact is still large and statistically significant in both the cluster and household level regressions. That is, the social capital of the households interviewed in the SCPS has an impact on the incomes of other households in their village (surveyed two years previously) as well as on their own incomes ${ }^{19}$. This is like finding that one household's land or asset ownership is important not only for their own but also for their neighbor's output. It is hard to overstate the importance and uniqueness of this result, as this implies that at least some significant fraction of associational life creates capital that is locally social.

Moreover, these results provide a powerful second argument against a causation from income to greater social capital. If individuals with higher incomes have greater social capital because social capital is a luxury (or even normal) good then one would expect the results would only appear when linking a given household's income to that same household's social

19 This similarity is all the more remarkable given the very low correlations of cluster level averages across the two surveys for most of the variables. The Spearman correlation coefficient is .42 for expenditures per person, .12 for average education, .13 for assets, .33 for median distance to market. 
capital $^{20}$. But this demand for association interpretation is not supported by the results in table 4 which show strong spillover impacts.

Before moving to the next section detailing the mechanisms of effect, let us pause and admit the results are somewhat an embarrassment of riches. We would not have guessed at impacts as large as those estimated, especially given all the obvious empirical difficulties in measurement, equation specification, etc. The instrumental variable estimates from SCPS imply that a one standard deviation increase in village social capital increases the income of all households in the village by approximately 50 percent and those using the HRDS by 20 percent. In more concrete terms, if half the village are members of one group (with average characteristics) this village would have a social capital index that is higher by one standard deviation than a village where group membership was zero ${ }^{21}$. While increasing average membership by one-half group per household (or changing group characteristics to a similar degree) is a substantial shift in social behavior, the estimates suggest this would increase expected incomes by 20 to 50 percent, which is an impressively large impact.

Either of these impacts on income is very large relative to other well-known determinants of income, such as schooling or physical assets. A one standard deviation increase in education, which is an additional 3 years of schooling per adult, would increase

${ }^{20}$ This is true unless all of the income variation across households is due to village effects, while in fact nearly all the observed variation in household incomes is due to non-cluster related household effects.

21 Since the index is multiplicative between group membership and the characteristics of groups matter and since the index is normalized twice it requires some working back to find out that, evaluated at the average group characteristics, increasing group membership by .5 would increase the social capital index by one standard deviation. 
incomes by only between 3 and 5 percent. Similarly, increasing non-farm physical assets by one standard deviation is associated with only a 19 to 22 percent increase in expenditures.

\begin{tabular}{|c|c|c|c|c|c|c|}
\hline \multirow[t]{3}{*}{ Variable: } & \multirow[t]{3}{*}{$\begin{array}{l}\text { Source of } \\
\text { estimates }\end{array}$} & \multirow[t]{3}{*}{$\begin{array}{l}\text { Point } \\
\text { Estimate }\end{array}$} & \multirow[t]{3}{*}{$\begin{array}{l}\text { Standard } \\
\text { Deviation }\end{array}$} & \multicolumn{3}{|c|}{$\begin{array}{l}\text { Increase in } \\
\text { expenditures from one std. } \\
\text { dev. increase: }\end{array}$} \\
\hline & & & & \multirow{2}{*}{ Percent $^{1}$} & \multicolumn{2}{|c|}{ Dollars ${ }^{2}$} \\
\hline & & & & & $\mathrm{HH}^{3}$ & $\begin{array}{l}\text { Per } \\
\text { person }\end{array}$ \\
\hline \multirow[t]{4}{*}{ Social capital } & SCPS, household & .56 & 1 & 56 & 655 & 101 \\
\hline & SCPS, cluster & .49 & 1 & 49 & 690 & 106 \\
\hline & HRDS, household & .19 & 1 & 19 & 222 & 34 \\
\hline & HRDS, cluster & .21 & 1 & 21 & 245 & 38 \\
\hline \multirow[t]{2}{*}{ Education } & SCPS, household & .009 & 3.21 & 2.9 & 34 & 5.2 \\
\hline & HRDS, household & .019 & 2.70 & 5.1 & 60 & 9.2 \\
\hline \multirow[t]{2}{*}{ Assets } & SCPS, household & .18 & 1.24 & 22 & 261 & 40 \\
\hline & HRDS, household & .14 & 1.36 & 19 & 222 & 34 \\
\hline
\end{tabular}

Incidental association, is this really social capital? There remains the possibility that the estimated effects of village social capital are merely an artifact and that social capital is proxying for some unobserved characteristic of villages (the omitted variable must be at the village, not household level to explain the HRDS results). It is impossible to reject this possibility econometrically, because village level "fixed effects" which would eliminate the 
potential bias would also preclude estimating the village level spillover effect of social capital that is the most interesting. We can however reduce the plausibility of incidental association and omitted variable bias stories in two ways.

First, we can ask how bad it could possibly be. If an omitted variable were biasing the social capital coefficient upward, the magnitude of the bias would be worse the larger the effect of this omitted cluster specific variable. The importance of excluded cluster variables can be examined by comparing the $\mathrm{R}^{2}$ of various regressions explaining household incomes. With only household characteristics the $\mathrm{R}^{2}$ is .262 in the HRDS; adding social capital and cluster distance to markets and agroclimatic dummies raises it to .291 , while adding the cluster averages of all the individual variables (education, assets, etc.) raises it further to .342 . A full set of cluster dummy variables in addition to the household characteristics raises the R-squared to .462 , so there is about 12 points of unexplained cluster variation. This relatively large variation in household incomes that is both cluster specific and unexplained by the included variables might suggest a potentially large omitted variables bias. However, the correlation of the cluster effect estimates across the two data sets is only .07 . This suggests the unexplained cluster variation is mostly temporary random shocks or measurement error and not due to some time persistent excluded variable correlated with social capital which would significantly bias the results 22 .

22 The alternative is that the lurking omitted variable is so highly correlated with social capital that its effect once controlling for social capital is very small. This however, begins to beg the question, as it is extremely unlikely the "omitted" variable and social capital are perfectly correlated unless both are in some sense a proxy for the same underlying social reality. 
The alternative tack for addressing omitted variable bias is the usual "kitchen sink" robustness test by adding to the regression all the cluster level variables for which we can create measures. The first row of table 6 shows the "base case" estimate while the following rows show the estimate of social capital with different sets of cluster specific variables added. Adding the cluster averages of all the household level variables already included in the regression only slightly lowers the estimate (and raises the t-statistic).

\begin{tabular}{||l|l|}
\hline Table 6: & $\begin{array}{l}\text { Robustness of the estimate on social capital to inclusion of other variables, } \\
\text { using the HRDS household level data. }\end{array}$ \\
\hline $\begin{array}{l}\text { Coefficient (t-statistic) } \\
\text { on social capital }\end{array}$ & Variables included \\
\hline $\begin{array}{l}193 \\
(2.31)\end{array}$ & Base set (table 4, column 1) \\
\hline $\begin{array}{l}.78 \\
(2.61)\end{array}$ & $\begin{array}{l}\text { Base set plus cluster averages of education, assets, household } \\
\text { size, female headship, self-employed in agriculture. }\end{array}$ \\
\hline $\begin{array}{l}.267 \\
(2.89)\end{array}$ & Base set plus land quality variable from SCPS \\
\hline $\begin{array}{l}.273 \\
(2.88)\end{array}$ & Base set plus land quality variable from HRDS \\
\hline $\begin{array}{l}155 \\
(2.01)\end{array}$ & $\begin{array}{l}\text { Base set plus district population density and financial institutions } \\
\text { per person. }\end{array}$ \\
\hline Notes: Full regressions in appendix 1. \\
\hline
\end{tabular}

The most plausible candidate for a variable that could cause both higher incomes and higher social capital and is excluded from our base case regression is land quality. As has been argued by Binswanger, Khandker and Rosenzweig (1993), higher quality land leads to higher output, greater density of population, and more physical and financial infrastructure. These greater levels of economic activity might in turn lead to greater social capital. We 
address the land quality question in two ways. In the SCPS households were asked to subjectively rank the quality of their land and of the land in the village generally. Including the village level land quality does not alter the strength or significance of social capital (and produces puzzling results) $)^{23}$. The next best is to add explanatory variables which ought to be related to land quality on this theory, such as population density and banking facilities per person $^{24}$. As seen in row 5 of table 6 the addition of these variables does not substantially alter the strength of the social capital effect.

\section{III) But how does social capital work?}

Econometric estimates show a large (and arguably causative) effect of a village's level of social capital on the incomes of all households in that village. Our understanding of this result is enhanced by understanding the proximate mechanisms through which social capital affects incomes in rural Tanzania. As reviewed in the introduction, the literature has suggested five plausible channels of influence each of which we now explore ${ }^{25}$.

23 The land quality variable is consistently negative in the income regression (although not always significantly so). This is likely due to the weakness of the subjective ranking, as when ranked on a scale of 1 to 5 a disproportionate number of individual responses were heaped on 3 which gives the data very little variation, a problem compounded by averaging over clusters.

${ }^{24}$ Although the story-line about bank activity following economic activity is mitigated in the Tanzanian case by the fact that the financial sector was completely dominated by one large parastatal, a famously non-profit maximizing commercial bank.

${ }^{25}$ Economists have perhaps tended to neglect the role of social factors in economic outcomes not out of any well-founded belief these were unimportant, but more because they were difficult to model and measure. In particular, there is a danger of confusing statements about what outcomes would be under the assumptions of purely individualistic behavior in which "market failures" are often discussed with actual positive statements about what would in fact happen. There is a clear role for social capital within any positive economic theory of actual 
Social capital and effective public services. Unfortunately, we do not have the clean natural experiment as in the Italian case studied by Putnam with creation of new regional governments with clearly assigned responsibilities. Tanzania since independence has been controlled by the same party which, although government is organized along provincial and district lines, has exercised centralized control over nearly all government and party activities. While there has been large emphasis on "cooperative" and "village" level organizations these were not autonomous locally controlled organizations, but a monopoly of the party ${ }^{26}$. This means that we cannot match data on social capital to the level of government jurisdiction formally responsible for the provision of public services. Therefore any effect of social capital on the effectiveness of publicly provided services must work indirectly, perhaps through greater cooperation of villagers in monitoring the performance of government, rather than directly through the formal political apparatus.

The HRDS has data on the quality of two government provided public services, schools and health clinics. While the objective "quality" of a school or clinic is difficult to measure, the HRDS measured the subjectively perceived quality using an innovative two step procedure. Households were first asked to rank the importance to them of each of five characteristics of their local school and health clinic, by allocating 20 stones across five pictures that represented facility characteristics. Each respondent was then asked to assess the quality of their local facility on those same characteristics on a scale of one to five. From these sets of questions an

social outcomes but modeling it convincingly is very difficult.

${ }^{26}$ In particular during the 1970 s the government pursued a policy of forced "villagization" which was neither particularly well received by those affected, nor successful. 
index of the subjectively perceived quality of each public facility (school or health clinic) can be constructed ${ }^{27}$.

The HRDS asked a series of questions about the level of parental and community involvement in the schools which allow us to construct an index of parental participation ${ }^{28}$. The HRDS also asked individuals about their attendance at "meetings where issues important to the community, such as health and education, could be discussed." Table 7 shows that social capital in the SCPS survey is associated with higher reported levels of parental participation in schools and attendance at community meetings in the HRDS data (which surveyed different individuals than those used to measure social capital). Moreover, higher social capital was associated with higher levels of school quality. These findings trace out a possible chain of causation from greater social capital to more parental and community involvement in schools to better quality schools. There is, however, no link at ail between health facility quality and social capital. This is perhaps not surprising as the major factors for health clinics were drug

${ }^{27}$ Arithmetically, quality index in the $\mathrm{j}^{\mathrm{jth}}$ village based on the $\mathrm{i}^{\text {ith }}$ household's assessed importance of the characteristic $\alpha_{c}$ and household's ranking of that characteristic $R_{c}$ is defined as: $Q I_{f}=\frac{\sum_{j=1}^{N /}\left(\sum_{c=1}^{S} \alpha_{c}^{\prime} * R_{c}^{\prime}\right)}{N_{j}}$.The principal difficulty with this measure at the cluster level is that there is little coherence among household's rankings of the same facility. That is, on each of the five rankings of school quality, within cluster differences account for more than 85 percent of the total variation, which raises some questions about reliability or interpretation of the rankings.

${ }^{22}$ The questions asked about the closest government primary school were: “Are parents asked to participate in decisions affecting the school [NAME]?" "Does the school have an active parents/teacher committee?" "Does the school [NAME] have open days for parents to visit?" "Does the school report grades?" 
availability and qualified doctors (appendix 2), factors which are largely beyond village control $^{29}$.

\begin{tabular}{||l|l|l|l||}
\hline \multirow{2}{*}{ Table 7: } & \multicolumn{3}{|c|}{$\begin{array}{c}\text { Correlation of social capital with indicators of parental participation in } \\
\text { schools, school quality, and health facility quality }\end{array}$} \\
\hline & & \multicolumn{2}{|c|}{ Bivariate rank correlations } \\
\cline { 3 - 4 } & & \multicolumn{1}{|c|}{$\begin{array}{c}\text { Social Capital } \\
\text { Index }\end{array}$} & $\begin{array}{l}\text { Group Functioning } \\
\text { Sub-Component }\end{array}$ \\
\hline $\begin{array}{l}\text { Median parental participation } \\
\text { in schools }\end{array}$ & HRDS & $\begin{array}{l}.243 \\
(.025)\end{array}$ & $\begin{array}{l}.202 \\
(.065)\end{array}$ \\
\hline $\begin{array}{l}\text { Attendance at community } \\
\text { meetings }\end{array}$ & HRDS & $\begin{array}{l}.296 \\
(.006)\end{array}$ & $\begin{array}{l}.117 \\
(.291)\end{array}$ \\
\hline $\begin{array}{l}\text { School quality } \\
\text { Health facility quality }\end{array}$ & HRDS & $\begin{array}{l}.176 \\
(.108)\end{array}$ & $\begin{array}{l}.238 \\
(.029)\end{array}$ \\
\hline HRDS & $\begin{array}{l}.132 \\
(.228)\end{array}$ & $\begin{array}{l}-.039 \\
(.724)\end{array}$ \\
\hline $\begin{array}{l}\text { Participation in joint efforts at } \\
\text { road repairs }\end{array}$ & SCPS & $\begin{array}{l}.147 \\
(.182)\end{array}$ & $\begin{array}{l}.272 \\
(.012)\end{array}$ \\
\hline Notes: p-levels in parenthesis. & & & \\
\hline
\end{tabular}

Social capital and village level cooperation Another possible channel for the impact of social capital is the management of resources that are treated as common property within the village (or perhaps among a few villages) such as improved water supplies, local irrigation capabilities, and local roads. Unfortunately on this question we have very little data, but in

29 While we do confirm an association between social capital, community involvement and better public services, we should point out that strictly speaking this does not go far in "explaining" the income effect of social capital as a proximate determinant, as we have no evidence on the magnitude of the link from better schools to higher incomes and moreover, in the data above the link with income and the quantity of schooling is quite weak in tables 3 and 4. 
the SCPS households were asked if they participated in joint activities aimed at building or maintaining roads. Villages with more social capital are more likely to have had community road building activities (table 7). This does suggest another possible link through village cooperative activity.

Social capital and agricultural practices. While each of the above illustrated some channel through which social capital affected outcomes, in neither could a solid link be made with higher incomes, which, given the economic context, are mainly determined by agricultural incomes. Much more important as a proximate determinant of incomes is that households in villages with larger social capital are much more likely to have used fertilizer, agro-chemical inputs, or improved seeds (table 8). A standard deviation increase in village social capital increases the probability of using agro-chemicals by 42 percent (6.7 percentage points above a mean of 16), of using fertilizer by 38 percent ( 5 percentage points) and of using improved seeds by 17 percent ( 2 percentage points). We also find that in villages with higher social capital a larger fraction of households report using credit for agricultural improvements. Since only 9 percent of households report using credit, the one standard deviation of social capital effect is to increase credit use by almost a third ( 2.7 percentage points). As with the income effects, these results are surprisingly strong. The positive association of the adoption of improved practices and credit use with social capital hold true whether one controls for the individual's self-reported land quality or extent of the individual's contact with an extension agent. 


\begin{tabular}{|c|c|c|c|c|}
\hline \multirow[t]{2}{*}{ Table 8: } & \multirow[b]{2}{*}{$\begin{array}{l}\text { Used Agro- } \\
\text { chemicals }\end{array}$} & \multirow[b]{2}{*}{$\begin{array}{l}\text { Used } \\
\text { fertilizer }\end{array}$} & \multirow[b]{2}{*}{$\begin{array}{l}\text { Used } \\
\text { Improved } \\
\text { Seeds }\end{array}$} & \multirow[b]{2}{*}{$\begin{array}{l}\text { Used credit } \\
\text { for } \\
\text { agricultural } \\
\text { improvements }\end{array}$} \\
\hline & & & & \\
\hline Village social capital & $\begin{array}{l}.057 \\
(2.35)\end{array}$ & $\begin{array}{l}.075 \\
(2.45)\end{array}$ & $\begin{array}{l}.015 \\
(.737)\end{array}$ & $\begin{array}{l}.027 \\
(1.66)\end{array}$ \\
\hline Household size & $\begin{array}{l}.012 \\
(3.25)\end{array}$ & $\begin{array}{l}-.006 \\
(1.43)\end{array}$ & $\begin{array}{l}.004 \\
(1.03)\end{array}$ & $\begin{array}{l}-.0019 \\
(.742)\end{array}$ \\
\hline $\begin{array}{l}\text { Average household adult } \\
\text { education }\end{array}$ & $\begin{array}{l}.019 \\
(5.00)\end{array}$ & $\begin{array}{l}.0078 \\
(1.56)\end{array}$ & $\begin{array}{l}.010 \\
(2.30)\end{array}$ & $\begin{array}{l}.0044 \\
(1.21)\end{array}$ \\
\hline Female Head & $\begin{array}{l}-.102 \\
(2.89)\end{array}$ & $\begin{array}{l}-.112 \\
(3.46)\end{array}$ & $\begin{array}{l}-.114 \\
(3.51)\end{array}$ & $\begin{array}{l}.0035 \\
(.143)\end{array}$ \\
\hline Assets & $\begin{array}{l}.049 \\
(2.45) \\
\end{array}$ & $\begin{array}{l}.110 \\
(6.28) \\
\end{array}$ & $\begin{array}{l}.058 \\
(2.63) \\
\end{array}$ & $\begin{array}{l}.0069 \\
(.606) \\
\end{array}$ \\
\hline $\begin{array}{l}\text { Self employed in } \\
\text { agriculture }\end{array}$ & $\begin{array}{l}.046 \\
(1.49)\end{array}$ & $\begin{array}{l}-.035 \\
(.958)\end{array}$ & $\begin{array}{l}-.037 \\
(1.06)\end{array}$ & $\begin{array}{l}.027 \\
(1.03)\end{array}$ \\
\hline Median distance to market & $\begin{array}{l}-.013 \\
(2.34)\end{array}$ & $\begin{array}{l}.005 \\
(.855)\end{array}$ & $\begin{array}{l}-.005 \\
(1.16)\end{array}$ & $\begin{array}{l}-.0052 \\
(1.51) \\
\end{array}$ \\
\hline $\begin{array}{l}\text { Observed probability } \\
\text { Pred. Probability at means } \\
\text { N }\end{array}$ & $\begin{array}{l}.217 \\
.155 \\
772\end{array}$ & $\begin{array}{l}.197 \\
.129 \\
734\end{array}$ & $\begin{array}{l}.169 \\
.125 \\
765\end{array}$ & $\begin{array}{l}.093 \\
.078 \\
842\end{array}$ \\
\hline Pseudo R-Squared ${ }^{3}$ & .204 & .254 & 147 & .071 \\
\hline \multicolumn{5}{|c|}{$\begin{array}{l}\text { Notes: 1) The t-statistics reported are the Huber corrected for the probit regression } \\
\text { coefficients, not the t-statistics of the reported marginal effects. } \\
\text { 2) Included in the regression but not reported were dummy variables for agro- } \\
\text { climatic zones, and for missing values of the assets, schooling, and distance to } \\
\text { market variables. }\end{array}$} \\
\hline
\end{tabular}

These results on the adoption of improved practices are consistent with at least three of the stories about the effect of social capital: innovation diffusion, overcoming market failures 
due to imperfect information, and informal insurance. There are arguments for and against each of these explanations of the differences in agricultural practices.

Innovation diffusion. The increased use of agricultural inputs is consistent with a story of better diffusion of information, both about the availability and the proper use of seeds, fertilizer and chemicals. However, given that clearly superior practices are usually adopted very rapidly and that the listed "innovations" have been around for some time it is doubtful this channel could explain such large differences.

Imperfect information. It has long been recognized that economic performance will be enhanced by a social situation in which market transactions are facilitated. This in turn is enhanced by greater degrees of confidence that one's potential partners are likely to be reliable and by greater information. This in turn is affected by a number of factors, such as the available mechanisms for formal or informal enforcement and expected compliance with social norms. Grief (1993) argues that personal ties and reputations among traders were an important part of the development of long distance trade. Transaction patterns generated by social ties in environments of weak formal enforcement are common, especially in business networks among ethnically or culturally similar groups.

Informal insurance. It could be that risk aversion among low income households inhibits the adoption of high return innovations if they are associated with higher risk. While each element of this story is plausible, there is no connection between the degree of inequality among households in the same village and social capital. In the same multivariate specification as used for the level of incomes, the social capital index has a zero estimated association with either the standard deviation of log expenditures or the coefficient of variation 
of expenditures (using data from both surveys). The estimated impact of social capital on median expenditures is quite similar (slightly higher) than for mean expenditures (whereas an effect that shifted the dispersion of log normally distributed incomes would affect these two differently). These findings suggest social capital appears to shift (natural log) expenditures upward without affecting the inequality of the distribution. It is possible that informal insurance increased incomes and the variance of incomes but that the variance increase in incomes is just offset so as the variance of expenditures is unchanged. However, the lack of association between expenditure inequality combined with the limitation that the data we have, which contain no direct evidence on intra household transfers or informal insurance, leaves the question open.

\section{Conclusion}

Using a specially designed large scale survey (SCPS) to measure the degree and characteristics of associational activity, as a proxy for social capital, and trust among households in rural Tanzania, we find that a one standard deviation increase in the village social capital index (as would be caused by half the village joining one additional group with average characteristics) is associated with at least 20 percent higher expenditures per person in each household in the village. The link between the social capital index from the SCPS survey and expenditures measured in an earlier survey of different households in the same villages (HRDS) shows convincingly this effect is social and operates at the village level. The social capital of a household's village is as important in determining the household's income as many of the household's own characteristics which receive a great deal of attention (e.g. schooling, 
assets or distance to markets, gender of household head). Social capital is an important, and so far largely missing, dimension of income and poverty analysis. Poverty analysis that focuses exclusively on the "capital" of individuals and ignores the local, community and social context could be missing a large part of the poverty puzzle (Narayan, 1997).

Moreover, we identify a number of theoretically plausible proximate mechanisms whereby social capital affects individual incomes. Households in villages with more social capital are more likely to enjoy better public services, use advanced agricultural practices, join in communal activities and use credit for agricultural improvements. These identified channels whereby social capital acts to increase incomes, together with the econometric robustness of the magnitude of the social capital effect to the use of instrumental variable estimation techniques, suggest that social capital is capital and not merely a consumption good.

While these results are very strong, we do not want to overstate the claims that can be supported by these results. First, while we do show that the level of social capital affects the level of income we do not make claims that the level of social capital affects the growth rate of incomes (but in this regard social capital is similar in its effects to physical and human capital). Second, there is clearly scope for institutional substitution in the modes of resolving these types of "market failure" in cooperation and while some may be social capital intensive others are likely to involve more formal, bureaucratic, technocratic, and less personalistic modes. It may well be that the problem is not so much with not having a deep associational network or not having a well run bureaucracy with impartial enforcement of rules but in not having either. Third, these results do not immediately generalize to all other social and economic contexts. 
The results of this paper alone are obviously insufficient as a basis for policy, but do raise important considerations and suggest exploration in several areas. First, since social capital is capital, investing in it is potentially beneficial to individuals, but since social capital is social it is unlikely that the market will produce the right amount. But that the market will not produce the right amount creates no presumption government action will produce the right amount either. This research has not empirically identified any policy levers available to expand social capital or estimated the costs of creating social capital ${ }^{30}$.

With the present state of knowledge, "do no harm" is probably the best guide. While seemingly platitudinous, this advice is non-trivial and has serious bite. Many would argue that the previous centralizing, technocratic and excessively narrow tendencies of some governments, and especially of development assistance, may have "mined" rather than created social capital and may have in fact done significant harm (Ostrom, 1995).

Second, these results are consistent with the increasing emphasis on both broadening and localizing decision making power. This is a common thread running through a number of different recent research and reform initiatives: greater emphasis on beneficiary participation (World Bank, 1994, Isham, Narayan and Pritchett, 1995, Narayan, 1995), greater role for local and development NGOs in service provision (Riddell and Robinson, 1995), decentralization (or federalization) and localization of public services (Binswanger, 1995), increased emphasis on community (Narayan, 1996), the (still too infrequent) use of "demand"

${ }^{30}$ One of the intriguing things about Putnam (1993) is that he traces the determinants of regional variations in social capital in Italy back hundreds of years to happenstance of ancient history. While this is great for solving the research problem of purging the estimates of joint endogeneity, since history is irreversible, it is not much help for policy. 
driven procedures in social funds, and recognition of the role citizen voice plays in the efficacy of government projects (Isham, Kaufmann, and Pritchett, 1996). The present results emphasize the role of local conditions but also raise the issue that with any delegation of responsibility or power to more "grassroots" levels, some communities are going to be more effective than others. While this is no argument against such reforms, this differential capacity (perhaps due to differing social capital) will need to be considered, with efforts to expand capacities of local weak groups. 
Biblingraphy

Ajuha, Vinod, 1996, "Land Degradation, agricultural productivity and common property: Evidence from Cote d'Ivoire," Mimeo: University of Maryland.

Alesina, Alberto, Reza Baqir and William Easterly, 1997, "Public goods and ethnic divisions," mimeo.

Besley, Timothy and Anne Case, 1994, "Diffusion as a learning process: evidence from HYV cotton," Princeton University Woodrow Wilson School of Public and International Affairs Research Program in Development Studies, Discussion Paper No. 174:1-19.

Binswanger, Hans P, Shahidur R. Khandker, and Mark Rosenzweig, 1993, "How infrastructure and financial institutions affect agricultural output and investment in India," Journal of Development Economics, 41:337-66.

Borjas, George J., 1994, "Ethnicity, neighborhoods, and human capital externalities," American Economic Review, 85(3):365-390.

Case, Anne and Lawrence Katz, 1991, "The company you keep: The effects of family and neighborhood on disadvantaged youths," NBER Working Paper \$3705 (May).

Coleman, James Samuel, 1990, Eoundations of social theory, Cambridge, Mass.: Harvard University Press.

Deaton, Angus, 1997, The Analysis of Household Surveys: Microeconometric Analysis for Development Palicy, forthcoming.

Easterly, William and Ross Levine, 1996, "Africa's growth tragedy: Policies and Ethnic divisions," Mimeo (World Bank).

Foster, Andrew, and Mark R. Rosenzweig, 1995, "Learning by doing and learning from others: human capital and technical change in agriculture," Journal of Political Economy, 103:1176-1209.

Fukuyama, Francis, 1995, Trust: the social virtues and the creation of prosperity, New York: Free Press.

Greif, Avner, 1993, "Contract enforceability and economic institutions in early trade: the Maghribi traders' coalition," American Economic Review, 83:525-48. 
Harrison, Lawrence E., 1992, Who prospers? : how cultural values shape economic and political success, New York, NY: Basic Books.

Isham, Jonathan, Deepa Narayan, and Lant Pritchett, 1995, "Does participation improve performance: Establishing causality with subjective data," World Bank Economic Review, 9(2):175-200.

Knack, Stephen and Philip Keefer, 1996 "Does social capital have an economic payoff? A cross-country investigation," mimeo (July).

La Porta, Rafael, Florencio Lopez-de-Silanes, Andrei Shleifer and Robert Vishny, 1997, "Trust in Large Organizations," Mimeo.

Morduch, Jonathan, 1995, "Income smoothing and consumption smoothing," Journal of Economic Perspectives, 9(3).

Narayan, Deepa, 1995, "The contribution of people's participation in 121 rural water projects," ESD Occasional Paper Series No. 1. World Bank: Washington DC.

Narayan, Deepa, 1995, "Designing Community Based Development," Environment Department Papers, Participation Series No. 7, The World Bank: Washington DC.

Narayan, Deepa, 1997, "Voices of the poor: Poverty and Social Capital in Tanzania," forthcoming ESD monograph series. Word Bank: Washington DC.

Olson, Mancur, 1996, "Distinguished lecture on Economics in Government: Big Bills Left on the Sidewalk: Why Some Nations are Rich, and Other Poor," Journal of Economic Perspectives, 10(2):1-24.

Ostrom, Elinor, 1990, Governing the commons: the evolution of institutions for collective action, Cambridge, England; New York: Cambridge University Press.

Platteau, Jean-Philippe, "Behind the market stage where real societies exist (Part I and II)," mimeo.

Putnam, Robert D with Robert Leonardi and Raffaella Nanetti, 1993, Making democracy work Civic traditions in modern Italy, Princeton, N.J. : Princeton University Press.

Putnam, Robert D. 1995, "Bowling alone: America's declining social capital" Journal of Democracy, 6(1).

Rogers, Everett, 1983, Diffusion of Innovations, New York: The Free Press. 
Wade, Robert, 1988, Village Republics, Cambridge: Cambridge University Press.

World Bank, 1993, Tanzania Social Sector Review. 


\begin{tabular}{||l|l|l|l|l|l|}
\hline \multicolumn{2}{|c|}{ Appendix table 2.1: School and health facility quality indicators } \\
\hline & $\begin{array}{l}\text { Mean } \\
\text { Weight }\end{array}$ & $\begin{array}{l}\text { Mean } \\
\text { Ranking }\end{array}$ & Characteristic & $\begin{array}{l}\text { Mean } \\
\text { Weight }\end{array}$ & $\begin{array}{l}\text { Mean } \\
\text { Ranking }\end{array}$ \\
\hline Characteristic & .252 & 3.18 & $\begin{array}{l}\text { Drugs always available } \\
\text { when you visit }\end{array}$ & .261 & 2.29 \\
\hline $\begin{array}{l}\text { Well qualified teachers } \\
\text { who teach children well }\end{array}$ & .188 & 3.41 & $\begin{array}{l}\text { Well qualified, } \\
\text { trustworthy doctors and } \\
\text { nurses }\end{array}$ & .228 & 3.12 \\
\hline $\begin{array}{l}\text { Excellent headmaster who } \\
\text { manages the school well }\end{array}$ & .245 & 2.46 & $\begin{array}{l}\text { Close to your homes, in } \\
\text { the village or ward }\end{array}$ & .165 & 2.91 \\
\hline $\begin{array}{l}\text { Enough supplies so each } \\
\text { child has a desk and } \\
\text { workbooks }\end{array}$ & .163 & 2.75 & $\begin{array}{l}\text { Clean, with toilet, safe } \\
\text { water, covered waiting } \\
\text { area }\end{array}$ & .155 & 2.93 \\
\hline $\begin{array}{l}\text { Clean building with toilets } \\
\text { and playground }\end{array}$ & $\begin{array}{l}\text { Public services: } \\
\text { sanitation, immunization, } \\
\text { control of pests }\end{array}$ & .189 & 2.98 \\
\hline $\begin{array}{l}\text { Emphasizes academics, } \\
\text { requiring no self reliance } \\
\text { work }\end{array}$ & .149 & 3.15 & & & \\
\hline Source: HRDS survey. & & & & & \\
\hline
\end{tabular}





\section{Policy Research Working Paper Series}

Title
WPS1773 The Costs and Benefits of Regulation: Implications for Developing Countries

WPS1774 The Demand for Base Money and the Sustainability of Public Debt

WPS1775 Can High-Inflation Developing Countries Escape Absolute Poverty?

WPS1776 From Prices to Incomes: Agricultural Subsidization Without Protection?

WPS1777 Aid, Policies, and Growth

WPS1778 How Government Policies Affect the Relationship between Polish and World Wheat Prices

WPS1779 Water Allocation Mechanisms Principles and Examples

WPS1780 High-Level Rent-Seeking and Corruption in African Regimes Theory and Cases

WPS1781 Technology Accumulation and Diffusion: Is There a Regional Dimension?

WPS1782 Regional Integration and the Prices of Imports: An Empirical Investigation

WPS1783 Trade Policy Options for the Chilean Government: A Quantitative Evaluation

WPS1784 Analyzing the Sustainability of Fiscal Deficits in Developing Countries

WPS1785 The Causes of Government and the Consequences for Growth and Well-Being

WPS1786 The Economics of Custorns Unions in the Commonwealth of Independent States

\section{Author}

J. Luis Guasch

Rotert W. Hahn

Valeriano F Garcia

June 1997

Date

June 1997

Contact

for paper

J. Troncoso

38606

J Forgues

39774

Maltin Ravailion

June 1997

June 1997

June 1997

Craig Burnside

David Dollar

June 1997

Szczepan rigiel

Tom Scott

Panos Varangis

Ariel Dinar

June 1997

Mark W. Rosegrant

Ruth Meinzen-Dick

Jacqueline Coolidge

June 1997

Susan Rose-Ackerman

Pier Carro Padoan

June 1997

L. Alan Winters

Won chang

June 1997

Glenn w Harrison

June 1997

Thom a F Ruthertord

David G. Tar:

John i. Cuddingtor

June 1997

Simon Commander

June 1997 Hamid R Davoodi

Une J Lee

Constantine Michalopoulos June 1997

David Tart
J. Ngaine

37947

J. Ngaine

37947

J. Ngaine

P. Sader

33902

P Kokila

33716

K. Labrie

31001

J. Jacobson 33710

M. Rigaud 30344

N. Busjeet 33997

37947

S King Watson 31047

E. Witte 85637

M. Pateña 39515 


\section{Policy Research Working Paper Series}

$\begin{array}{llll}\text { Title } & \text { Author } & \text { Date } & \text { Contact } \\ \text { for paper }\end{array}$

Theory of Education Spending 